\title{
AND THE HEAT GOES ON: POLICE REPRESSION AND THE MODALITIES OF POWER
}

\author{
HOWARD LIU AND CHRISTOPHER M. SULLIVAN
}

AbSTRACt. Among security institutions, police occupy a unique position. In addition to specializing in the repression of dissent, police monitor society and enforce order. Yet within research studying state repression, how police institutions are used and deployed to control domestic threats remain under-explored, particularly as it relates to the dual functionality just described. In this study, we develop and test an explanation of police repression accounting for the bifurcation of Mann's two modalities of state power: infrastructural power and despotic power. Infrastructural power allocates police resources to surveil dissidents and preemptively limit dissent's emergence or escalation. Police deploy despotic power through repressive responses to political threats. Empirically, we employ unique data to investigate police repression and the modalities of power in Guatemala. To analyze how shifting the balance between infrastructural and despotic power affects police repression, we isolate damage occurring from an earthquake that exogenously reshaped the landscape of infrastructural power. Results affirm the role of infrastructural power in regulating the despotic power of the state. Where local infrastructure was most affected by the earthquake, the security apparatus lost the capacity to surveil nascent movements and predict their activity, thereby providing opportunity for dissidents to mobilize and forcing police to (over-)react rather than shutdown resistance preemptively. However, the intensity of state violence recedes as the state recovers from the infrastructural damage and regains its control of local district.

Keywords: Policing, Repression, Political Order, Conflict

Howard Liu: Department of Government, University of Essex, UK. Christopher M. Sullivan: Department of Political Science, Louisiana State University, USA. 
States apply a diverse range of repressive tactics in their efforts to maintain political order. For example, governments arrest, torture, and kill dissidents to squash mobilization; they also track and surveil emergent organizations to deter resistance before it emerges (Tilly et al., 2003; Davenport, 2009; Sullivan, 2019; Ritter and Conrad, 2016). At the extreme, tactics of mass killing are deployed to violently remove civilians surrounding/supporting insurgent challengers (Valentino, Huth and Balch-Lindsay, 2004). But while there remains little disagreement over the willingness of states to repress political dissidents, at present the microfoundational evidence on whether repression systematically improves or weakens political order remains inconclusive (Davenport, $2007 a) .{ }^{1}$ When repression fails, it creates backlash, reshaping political alliances and weakening state authority (Lucas, 1998).

Equally puzzling, states employ starkly different levels of repression to govern their societies. States like Somalia apply widespread violence to suppress challenger groups, while states like China utilize their security apparatus to detect and repel potential threats with more limited reliance on overt repression. Governments also vary in their application of coercive force across community groups and across territory, as evidence from recent exposures of police violence in the United States make abundantly clear. Existing literature on state repression does not yet provide satisfactory explanations specifying the conditions under which different levels of repressive severity are applied (Davenport, 2009; Hill and Jones, 2014).

To explain repression, we differentiate two modalities of state power: "infrastructural power" and "despotic power" (Mann, 1984). The modalities are differentiated both by the technologies through which power is applied and by the corresponding coercive practices

\footnotetext{
${ }^{1}$ Repression appears to support political order in some scenarios, while having no effect or even contributing to backlash in others. Even less is known about the long-run legacies of coercion on political attitudes and behavior.
} 
they prescribe. ${ }^{2}$ Infrastructural power allocates resources to state institutions administering bureaucratic authority and enforcement; despotic power involves repression intended to counter political challenges. The former draws individuals into routine contact with the state's legal apparatus, enabling preemptive action to detect and manage nascent threats. The latter deploys units to specific locations in order to respond to dissent and maintain order. Based on this theoretical distinction, we argue that states substitute between these two methods of political control (Moore, 2000). When the state has strong infrastructure to monitor and control society, it can preemptively neutralize dissent before it breaks out. In contrast, when the state has limited infrastructural power, it substitutes severe repression in response to dissident threats.

Among security institutions, police occupy a unique position at the intersection of the two modalities of power. Simultaneous to their role in monitoring society to identify rogue behavior, police represent a core institution specializing in the identification and repression of political dissidents (Gurr, Grabosky and Hula, 1976). While police institutions have yet received enough attention in the repression literature, a growing body of research begins to take a closer look at it, investigating how police force and its institutional design help the state reinforce local control and preserve order during civil conflict (Arriola et al., 2020) and the ways in which governments increase civilians' trust in police by initiating reform in peace time (Blair and Morse, 2020; Curtice, 2020). In this study, we specifically focus on how local infrastructures shape police repression strategy during civil conflict. To analyze how shifts in the balance between infrastructural and despotic power affect police repression, we employ data from the Guatemalan National Police Archive to identify subnational variation in police repression. Our analyses exploit a regression discontinuity

\footnotetext{
2 "Power", according to Giddens (1995), involves, "the transformative capacity of human action, the capacity of human beings to intervene in a series of events so as to alter their courses." Repression involves "actual or threatened use of physical sanctions against an individual or organization, within the territorial jurisdiction of the state, for the purpose of imposing a cost on the target as well as deterring specific activities and/or beliefs perceived to be challenging to government personnel, practices or institutions" (Davenport, 2007a).
} 
design to study how infrastructural damage incurring from a large earthquake in 1976 reshaped the landscape of police repression. Because earthquake damage is exogenous to prior repressive efforts and infrastructural development, our earthquake-based research design identifies a shock needed to assess plausibly exogenous changes in infrastructural power.

Results affirm the role of infrastructural power in regulating the despotic power of the state. Where local infrastructure was most affected by the earthquake, the security apparatus lost the capacity to surveil nascent movements and predict their activity, thereby providing opportunity for dissidents to mobilize and forcing police to (over-)react rather than shutdown resistance preemptively. However, the intensity of state violence recedes as the state recovers from the infrastructural damage and regains its control of local district.

These findings contribute to the literature on state repression and political order in at least three ways. First, previous literature has put much emphasis on viewing state repression as a response to acts of dissent. We direct research to also consider how policing infrastructure facilitates political control, thus limiting the need to supply repression. Secondly, this study contributes to research studying substitution among repressive tactics and specifies how power affects the substitution of police violence. Lastly, our focus on change in local infrastructure stresses the need to explain state violence at the subnational level. Cross-national studies typically consider aggregate, slow moving measures of state capacity. By examining local-level variation, we identify previously hidden infrastructural mechanisms affecting decisions to repress.

The remainder of this study proceeds as follows: In the next section we dissect the theoretical distinction between infrastructural power and despotic power. After identifying feedback between the two modalities, we then develop a theoretical account that predicts how changes in infrastructural power distort police repression. We then describe the historical context of the Guatemalan case before detailing the data and measurement 
strategy. The analysis tests the argument against rival accounts drawn from prior literature. We conclude by discussing the study's implications for conflict, repression, and political order.

\section{Policing And the Modalities of Power}

State power and the enforcement of political order remain canonical topics of empirical inquiry. Within this line of research, state capacity remains among the most studied factors predicting threats to political order. State capacity shapes the onset and dynamics of civil war as well as violent protests, terrorism, and revolution (Goldstone and Tilly, 2001; Fearon and Laitin, 2003; Sobek, 2010; Sullivan, 2019). The theory underlying this relationship argues that state capacity provides an indicator of the state's repressive capabilities. To deter and counter attempts to disrupt existing order, states wield repression against organized political challengers. Repressive actions shape the origins of dissident as well as its ebb and flow (Tarrow, 1998). Reactive repression responds to ongoing acts of dissent by targeting challengers to impose costs and limit future actions, while preemptive repression attempts to limit mobilization before challengers take to the streets (Sullivan, 2016; Ritter and Conrad, 2016; Blaydes, 2018).

Critically for states, repressive threat management constitutes only a piece of the broader puzzle of political order. In addition to responding to the threat of conflict with repression, states endeavor to prevent or regulate emergent challenges. States seek to contain emergent threats through institution building, legal procedure, and judicial enforcement. Governments also wield their legal authority to prevent the emergence of collective challenges and/or to contain their escalation, as for instance when specific groups of challengers are targets of restrictions on freedom of assembly. As these strategies directly relate to the onset and intensity conflict, they have recently been integrated into research on political violence (Sullivan, 2016; Ritter and Conrad, 2016; Blaydes, 2018). 
To better understand how coercive response conjoins with threat prevention, it is useful to revisit Mann's distinction between despotic power and infrastructural power. As conceptualized by Mann (1984), despotic power includes, "the range of actions which the elite is empowered to undertake without routine, institutionalized negotiations with civil society." In its bluntest form, despotic power involves repression used to suppress political challenges. In Mann's words, infrastructural power includes the ability to "penetrate civil society and to implement logistically political decisions throughout the realm" (ibid.). Infrastructural power flows through systems of tax and transfer, education, conscription, and law enforcement, among other institutions (Weber, 1976). If despotic power represents the power to act against challengers, infrastructural power, represents the power to act through (i.e., regulate, channel, and direct) challengers.

Acknowledging that there is no unifying explanation of the direction, speed, or scale of the relationship between despotic and infrastructural power, we identify several mechanisms connecting infrastructural power to the state's application of despotic power. First, states may buildup the repressive bureaucracy in response to perceived threats. Individuals tasked with carrying out repressive campaigns may develop institutional systems of information collection that systematically distort the appearance of threats, leading to a misalignment of repression and dissent (Cunningham, 2004). Given increased autonomy to manage threats, repressive institutions generate an interests in perpetuating violence even as the underlying threat begins to abate (Stanley, 1999; Greitens, 2016). If the bureaucracy's incentives become misaligned from those of the administrative state, it could develop an internal logic reproducing repression in ways that run counter to government strategy. As the reach of the repressive apparatus grows and it accumulates control over other state agencies, the "growth of the garrison state" produces a regime that sees war making and state making as means of government (Gurr, 1986).

At the same time, critical junctures configuring infrastructural power could provide opportunities to redesign repressive institutions. At the national level, its expected that 
large institutional changes will reflect the nature of political threats at the time of institutional development (Greitens, 2016). Locally, the empirical expectation is less clear. Local politics may lead to institutional reforms that promote repression in some localities while limiting despotic power in other sites.

A second, distinct reflection on the intersection of the two modalities suggests the effectiveness of despotic power remains largely conditional on the infrastructural power operating at a given point in time or a given location within the state. Through its bureaucracies, states extract resources, develop and enforce law, arbitrate social disputes, administer elections or other forms of government selection, and ensure the continuation of socio-economic order. All of these facets are more difficult when the state has limited ability to penetrate society and make sense of social behavior (Scott, 1998; Blaydes, 2018).

\section{Infrastructural Power and Repressive Substitution}

Through infrastructural power, the state preempts challengers by systematically shaping individual and collective action through administration, bureaucratic procedures, and regulation. Foucault (1991) refers to the power to regulate as the "conduct of conduct." With regard to conflict and statebuilding, Yashar (1999) connects the expansion of infrastructural power to fewer unintended consequences resulting from state action, and Yashar (2005) shows that low infrastructural power facilitates challenger mobilization. Recent research further shows how coercive and infrastructural power impact violent dissent, with high infrastructural power appearing to reduce challenger violence (Sullivan, 2019). ${ }^{3}$

The strategic use of the two powers - governing infrastructure that facilitates threat prevention and a security apparatus engaging in coercive response-provides the state different ways to control the populace. Which power is deployed in any given scenario is

\footnotetext{
${ }^{3}$ Notably, in situations where rebels capture and control territory, state legacy infrastructure may remain largely intact even as the surveillance capacity of the government drops. Given rebel strength, situations of rebel control can provide the state with incentives to "do nothing" rather than ramp up repression.
} 
determined by the state's resources and the relative balance between the two modalities. Linking the two forms of power back to conflict, the generation of infrastructural power can be a highly coercive process. As a historical fact, states used conflict to expand their authority into uncontrolled spaces. The local population had to be, "transformed into obedient subjects by the work of state institutions" (Schlichte, 2007). Mutually supportive mechanisms (through which the two modalities of power can sharpen the state's control over domestic politics) reflect only a piece of this complex puzzle. Conflict can also weaken state institutions, as contention drains the state of resources that could otherwise be devoted to advancing infrastructural power. ${ }^{4}$ Weak states, in turn, appear uniquely acceptable to intense conflict (Collier et al., 2003).

Engaged in both preemptive repression and reactive repression, police operate at the intersection of infrastructural and despotic power. Police patrol neighborhoods, open and close traffic routes, investigate, and enforce legal statutes. Simultaneously, police surveil dissident networks, regulate protest sites, and detain challengers. Literature on policing and conflict prioritises their role repressing political protests, often ignoring their complicated institutional mandate to monitor and deter deviance (Earl, 2011). Some recent work starts investigating how police force and its institutional design help the state reinforce local control and preserve order during and after civil conflict (Arriola et al., 2020). Direct examination of police forces and repressive substitution under diverse structural contexts offers a window into the complex mechanisms transecting the two modalities of power. Local institutions serve as the most direct connection linking police to infrastructural power. Within conflict, the origins, intensity, and outcomes of political contention vary substantially across space and time. Correspondingly, police deployed in and around conflict zones vary in their assigned duties, their resource allocations, and the intensity with which they direct repression locally.

\footnotetext{
${ }^{4}$ Though related research considers how shocks to public goods expenditures affects conflict, our focus here more narrowly attends to how shocks to monitoring and surveillance infrastructure impact subsequent repression (cf., Savun and Tirone (2012)).
} 
Building on these theoretical mechanisms, we describe a process through which shifts in the balance of infrastructural and despotic power affect police repression. ${ }^{5}$ First, we believe that strong infrastructural power drastically improves the likelihood that would be dissidents are deterred from taking action against the state. The buildup of infrastructural power increases monitoring and surveillance as well as routine interactions with political institutions. Information accumulation raises probability that an individual will be sanctioned should they begin to mobilize. As Slater and Fenner (2011) note, repressive deterrence works best when, "citizens know, or assume, that they are legible to the regime through their various interactions with the state." Second, we contend that increasing infrastructural power makes acts of preemptive repression more targeted and more effective, limiting the likelihood that conflict escalates repression through a process of coercive response. Combined, increasing the probability of repression targeting early mobilizers screens out a large percentage of challenger groups (Ritter and Conrad, 2016). If possible, states would much prefer to prevent demonstrations and rebellions before they occur rather than taking punitive measures reactively.

When dissidents weigh the potential costs of repression yet continue to organize against the regime, greater infrastructural power increases the state's ability to identify their preliminary mobilization activities and quash these actions without doling out additional punishment on the civilian population. Repressing mobilization reduces the ability of dissent to escalate, both by depleting the dissident's organizational infrastructure and by minimizing potential backlash mobilization (Sullivan, 2016). Regimes substitute between these two methods of political control. In the wake of a shock to one power, we anticipate a transfer to the other. When the state has strong policing infrastructure and information to monitor and control society, it can preemptively neutralize dissent before it occurs, making reactive repression less necessary. However, when sudden shocks deplete the

\footnotetext{
${ }^{5}$ The mechanisms speak to theories specifying the "substitution of repressive tactics" (Moore, 2000; Fariss and Schnakenberg, 2014).
} 
state's infrastructural power for threat prevention, a shift of repressive tactics is needed. The state will rely more on direct repression in response to dissent to maintain order. With the recomposition of infrastructural power, the situation will return to its prior institutional configuration, in which high infrastructural power limits need for reactive repression.

H1: Destroying state infrastructural power will increase repression; reconstructing infrastructural power will reduce repression.

Accounting for repression requires breaking apart the two modalities to identify how shifts in infrastructural power impact despotic repression. A primary difficulty lies in the fact that repressing dissent can be endogenous with state's infrastructure building. Increased repression and policing (potentially due to greater dissent challenges) can draw more financial resources to those districts where infrastructural buildup and surveillance network development are needed to control the society. Therefore, infrastructure building may not be random and could potentially be related to the repressive needs in local districts. This endogeneity concern creates threats to inference. Natural disasters, however, provide abrupt shifts in infrastructural power. In addition to providing an exogenous shock, disasters also speed up historically slow processes of infrastructure building as state reconstruction takes place far quicker than state construction. Our analyses below exploit such a natural shock to state infrastructure in order to test our expectation that shifts in infrastructural power lead to tactical substitution and systematic changes in police repression.

\section{CASE AND DATA}

This study analyzes subnational variation in repression within Guatemala between 1976-1982. The particularities of the case reveal a number of important facets relevant to this study. In 1976, Guatemala was ruled by a military-backed government. Using 
the police, military, and paramilitary units, General Kjell Laugerud García waged a repressive campaign against urban labor unions sympathetic to communism and a variety of rural insurgent bands, which were holdovers from an earlier coup that fractured the government. General Romeo Lucas García took power through a fraudulent election in 1978. During Lucas García's regime, the use of extrajudicial killings, torture, and disappearances escalated as the government continued to ramp up repression. Beginning in 1980, the government's repressive efforts expanded to include village massacres. ${ }^{6}$ However, discontent within the military led to a coup that installed General Efrain Rios Montt. Under Rios Montt's direction, repression took on a new level of intensity between 1982 and 1983, during which time the government engaged in a broadly targeted campaign applied against large segments of society. ${ }^{7}$

As our focus is on police repression, we direct our attention to the actions of the Guatemalan National Police. The National Police held jurisdiction over the entire country throughout the period under review. Their responsibilities included maintaining a vast surveillance operation (Weld, 2014). In addition, the police were responsible for arresting, torturing, and killing individuals identified as threats to the state (Brockett, 2005; de la Policia Nactional, Aguirre and Doyle, 2013; Guberek and Hedstrom, 2017). They also carried out more routine policing operations, such as clearing streets, corralling demonstrations, and monitoring highway traffic.

Local-level measures for repression as well as a host of relevant covariates are gathered from a unique archive of previously confidential documents produced by the Guatemalan National Police. For approximately one hundred years, the Guatemalan National Police stored their records in a large warehouse on the edge of Guatemala City. When the National Police were disbanded as part of the country's peace accords (which broadly

\footnotetext{
${ }^{6}$ Studying spatial variation in these massacres, Sullivan (2012) finds that massacres were less likely to occur in settings where the state had strong infrastructural power (proxied by urban development, literacy rates, and the presence of state-sponsored militias).

${ }^{7}$ We conclude our study with the March 1982 coup.
} 
reorganized the security apparatus), the warehouse was abandoned along with millions of internal police records (e.g., memos passed up and down the chain of command, arrest records, log files summarizing daily activity, and investigative reports produced by local divisions, the central command, or more specialized units). The records sat in various stages of disarray and decomposition for nearly a decade before being discovered in 2006 . Following years of work cleaning, organizing, and indexing the files, the Archive of the Guatemalan National Police (AHPN) was finally released to the public in 2009.

To collect data for this project, a specially selected subset of the approximately 10 million documents dated between 1976 and 1982 were read and coded into an events database. Following a multi-stage sampling procedure, the project read more than 300,000 files, including every file sent to the Director General's Office and the Office for Coordinating Military and Police Activity. A team of researchers read each file and coded all politically relevant events into a database including nearly one hundred event types. ${ }^{8}$ For each event, the database identifies the municipality and month in which it occurred. Guatemala's 326 municipalities are the country's second smallest administrative unit. The least populous was San Jose Chacaya (with 567 inhabitants) and the most populous was Guatemala City (with 700,460).

What makes the AHPN data so unique is that the source material was produced by a bureaucracy that never believed its records would be made public. And perhaps more significantly, the documents were released without oversight by those responsible for repression. As a consequence, the collection represents one of the most transparent and comprehensive sources of data on police repression identified to date (Sullivan, 2016).

Measurement. To analyze infrastructural power, we leverage the country's 1976 earthquake and the geographically discontinuous damage across earthquake struck zones. The Guatemalan earthquake struck on February 4, 1976 with the maximum magnitude of 7.5.

\footnotetext{
${ }^{8}$ We exclude all repressive events not involving the National Police.
} 
The shock was centered on the Motagua Fault, about $160 \mathrm{~km}$ northeast of Guatemala City at a depth of 5 kilometers (3.1 mi) near the town of Los Amates in the department of Izabal.

In the immediate aftermath of the earthquake, the first priority of the police was to restore transportation, particularly the highway running from Guatemala City through the most damaged regions and connecting the capital to Puerto Barrios, the country's most important port. Telephone lines, electricity, sewage, and access to potable water were all severely disrupted for hundreds of thousands of Guatemalans. In addition to maintaining a public presence to assist citizens and deter crime, police directed citizens to distribution warehouses set up by the Guatemalan government to allocate aid. Intelligence reports remained within the traditional police chain of command, though the Director of the Police also began to forward municipal intelligence to the National Emergency Committee in charge of coordinating disaster relief.

As time wore on, temporary housing started to give way to rebuilding efforts. Bilateral and multi-lateral aid flowed into the country, with most of it intended to provide food aid, establish, temporary shelters, and then rebuilding local housing stock. Police monitored the reconstruction at the local level, keeping an eye on how political organizations were mobilizing around issues of land rights, economic uncertainty, and demands for redistribution. Gawronski and Olson (2013) contend that the earthquake, "changed the nature and the scope of...organizing, generating a completely new level of public (and especially indigenous) involvement in local affairs." For the political and military elite, this was seen as a two fold problem. First, the local activists were seeking to use the post-disaster political uncertainty to assert new rights. Second, these organizations would then threaten long-established racial-ethnic and economic hierarchies. As the Guatemalan National Police attempted to monitor the origins of these new political organizations, they found themselves running up against new challenges. Many of the displaced indigenous communities were organizing in languages foreign to even local police. Reconstruction itself also 
served as a mobilization tool, as the country began to rebuild through the establishment of agricultural and credit cooperatives. Lastly, NGOs were granted new political rights as part of the reconstruction process. Cumulatively, this left police facing new and uncertain threats without reliable intelligence networks.

The earthquake occurred along the Motagua Fault, which runs roughly NE-SW across the most heavily populated parts of Guatemala. The epicenter of the main shock was about 115 kilometers northeast of Guatemala City, and ground breakage was observed for more than 240 kilometers along the fault. Movement was also detected on a number of secondary faults, several of which extend into the outskirts of Guatemala City. There were hundreds of aftershocks with the largest being approximately 6.0 on the Richter scale causing further damage, especially to already weakened structures occurring on 6 February (Espinosa, 1976). Figure 1 shows the Motagua Fault line as well as infrastructure damage in affected areas. The fault runs across six departments - Chimaltenango, Guatemala, El Progreso, Sacatepequez, Quiche, Zacapa, though the damage was concentrated in more populous departments, such as Chimaltenango, Guatemala, El Progreso, Sacatepequez.

A field report of the earthquake's damage was conducted shortly afterward by the World Bank (Olson and Stuart Olson, 1977). The report details the level of material damage in affected municipalities. In this assessment, material damages include roads blocked due to rockslides, houses collapsed due to lateral movement, and power outage. ${ }^{9}$ To create our indicator of infrastructural damage, we use the material damage report and estimate the municipal damage repair over time. We estimate the repairs using a commonly used exponential decay formula based on municipal distance from the capital and time passed (Poulin, 2003; Masuda, Miwa and Konno, 2005). The formula is typically written in the following form:

\footnotetext{
${ }^{9}$ American researcher Frederick Bates wrote a detailed report "Recovery, Change, and Development: A longitudinal Study of the 1976 Guatemalan Earthquake" which documents various types of infrastructural destruction. The destruction includes damages of road transportation, local housing and buildings, electricity, and communication systems. A table summarising different categories of infrastructural damages is reported in Appendix Figure A.2.
} 
Figure 1. Major Earthquake Shocks and Damage by Municipalities, 1976

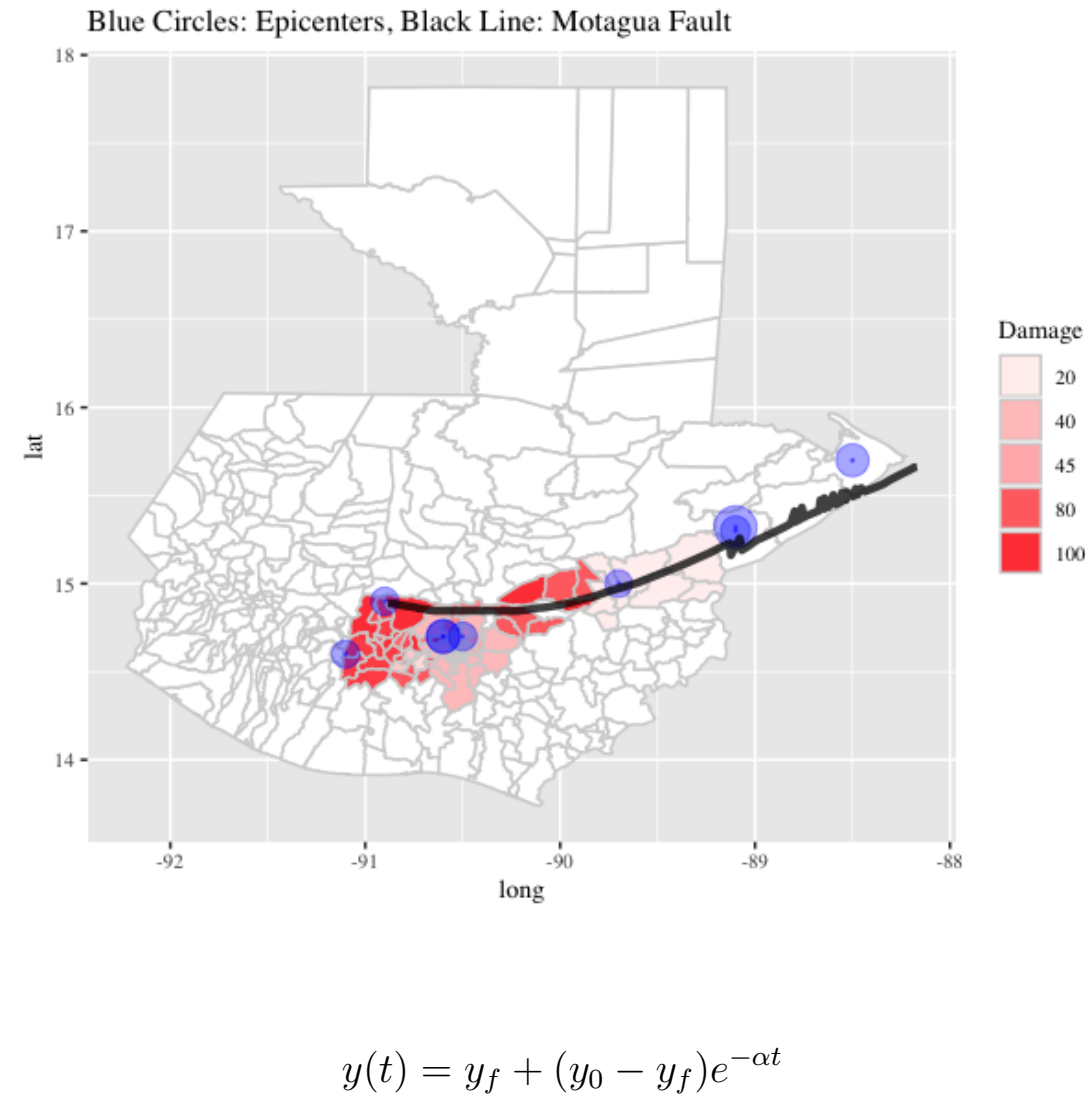

where $y(t)$ is the damage level we estimate for each year as municipalities progressed in their recovery since the earthquake in 1976. $y_{0}$ is the original level of the damage (on a scale of 0 to 100) indicated by the field report, and $y_{f}$ is the last year of our observations (1982) when the material damage was largely recovered to the level prior to the earthquake (Bates, Killian and Peacock, 1984). The damage repair rate is determined by the exponential term in which $\alpha$ represents the inversely weighted municipal distance to the capital city and $t$ is the number of years after the earthquake. The exponential decay term $e^{-\alpha t}$ with a negative exponent shows that a municipality would recover faster if it is closer to the capital city of Guatemala and when more years have passed after the earthquake. ${ }^{10}$ It is worth noting that the geography in Guatemala contains variant

\footnotetext{
${ }^{10}$ More details are illustrated in the appendix section 1.
} 
elevations so we use road distance instead of geodesic distance to measure spatial proximity to the capital.

Alternative Explanations. A large literature developed over the past three decades to study levels of human rights abuse. In accounting for levels of repression, the dominant approach relies on government efforts to protect itself from observed challenges to its rule (Moore, 2000; Davenport, 2007a; Nordås and Davenport, 2013). As challenges to the government arise, repression is deployed to defeat the challengers and pacify the populace. Similarly, when challenges abate, repression should decline. Two variables are to used examine political challenges. Overt challenges is a variable measuring mass demonstrations, such as protests and rallies. Insurgent violence is a count of armed attacks by organized groups challenging the government. Both variables are derived from the AHPN data and represent monthly event counts identified for each municipality. Additionally, we also control for the municipal Population to proxy the latent propensity of mass dissent activity in the local district.

Additional research drawing from this same data shows that government repression sometimes anticipates dissident activity by targeting the mobilization behaviors of would be challengers (Sullivan, 2016). We thus include the Mobilization activities variable which measures behaviors designed to increase the level of formal organization associated with a claims-making effort. Unlike overt, collective challenges, which are public shows of political force directed at authorities, mobilization activities are generally clandestine. Examples of mobilization activities captured in the data include the distribution of information, organizational meetings, training sessions, and recruitment efforts. This variable is measured monthly as a municipal-level event count.

Alongside threat response theory, there is a more recent stream of research focused on understanding how different institutions might be associated with repression. Where 
threat response theory conceives of a government that is utilitarian in its use of repression, much of the institutional work sees coercion originating within the structure of the state. Research within this tradition believes that coercive institutions are capable of being contained, but only if the right set of rival domestic political institutions can be put in place to restrain the repressive apparatus. Most prominently, regimes governed by more democratic institutions have been found to be significantly less repressive than regimes that do not hold such institutions (De Mesquita et al., 2005; Davenport, $2007 a, b$ ). Thus, we consider two measures of democracy in our analysis. The first, Democratic inclusion, is measured using the standardized Coppedge et al. (2016) metric that identifies annual changes in national indicators of inclusion, such as suffrage rights and the selection processes for legislatures and executives. Democratic inclusion varies only across time and thus possesses limited capacity for explaining spatial variation in human rights improvements. A second variable, Campaign activity, measures all public activities organized by representatives of political parties. Campaign activities provide an indication that political competition has developed sufficiently for parties to take interest in a municipality. Monthly, municipal-level counts of campaign activity come from the AHPN data.

A third distinct body of institutional research focuses on principal-agent dynamics operating within the state's security forces (Earl and Soule, 2006; Butler and Mitchell, 2007; DeMeritt, 2015). Principal-agent arguments contend that in settings where governmental principals lack oversight and sanctioning abilities, agents are more likely to allocate repression in line with their personal incentives, rather than principal directives. ${ }^{11}$ To proxy oversight, we employ data from the CIA to identify the sites of permanent police headquarters operating during the period under review (Doyle, 1999). The variable Headquarters location identifies whether a municipality was the site of a headquarters. The variable Headquarters distance measures the average distance each municipality was

\footnotetext{
${ }^{11}$ Earlier studies used measures of infrastructural power as an indicator of principal oversight (e.g., Butler et al. 2007).
} 
operating from any other headquarters. The descriptive statistics for the variables in use are presented in Table 1.

Table 1. Descriptive Statistics

\begin{tabular}{rlrrrr}
\hline & variable & mean & sd & min & $\max$ \\
\hline 1 & Police Repression & 0.03 & 0.17 & 0.00 & 1.00 \\
2 & Motagua Fault Line & 0.20 & 0.40 & 0.00 & 1.00 \\
3 & Infrastructural Damage & 11.52 & 25.99 & 0.00 & 100.00 \\
4 & Overt Challenges & 0.03 & 0.24 & 0.00 & 6.00 \\
5 & Mobilization Activities & 0.02 & 0.38 & 0.00 & 54.00 \\
6 & Campaign Activity & 0.00 & 0.03 & 0.00 & 2.00 \\
7 & Insurgent Violence & 0.03 & 0.24 & 0.00 & 6.00 \\
8 & Ln Population & 9.16 & 0.89 & 6.34 & 11.77 \\
9 & HQ Location & 0.08 & 0.27 & 0.00 & 1.00 \\
10 & HQ Distance & 0.53 & 0.17 & 0.18 & 1.38 \\
11 & Democratic Inclusion & -4.57 & 1.47 & -8.00 & -3.50 \\
\hline
\end{tabular}

Qualifications. Before continuing, it is useful to identify some assumptions that are not frequently discussed within the literature but which nevertheless influence work in the area. Such a discussion outlines the general parameters of the research, but is not subject to investigation.

First, regarding the scope conditions of the argument, as the theoretical dynamics consider interactions between the government and potential claims-makers, a primary concern must be that the government is facing some (minimally) organized opposition. There must also exist some minimum amount of surveillance capacity necessary for identifying at least some acts of mobilization. And the government must be deploying coercion to enforce compliance with its authority, rather than remove or destroy the local population. Concerning the form of repression, the study is concerned with de facto rather than de jure forms of repression. While legalized restrictions (such as general curfews and prohibitions on assembly) are designed to influence challenger formation and strategy, the approach taken here is concerned exclusively with discreet, observable acts of repression, which may or may not be legally. 
Second, the broader context in which the modalities of state power operate must be considered. National and international institutions may impose constraints on the form of repression deployed as well as structure opportunities for activists political engagement. For instance, advanced democracies repress at lower rates than their autocratic or semidemocratic counterparts. Our theory and analysis consider a police force that is able to repress with impunity. As such, it would be reasonable to limit generalizing our findings only to police repression in conflict ridden, non-democratic states. Simultaneously, the organizational field within which challenger groups operate can influence claims-making strategies both domestically and internationally. The analysis below examines variation in the decision to repress within the context of a single shock to infrastructural power operating within one regime, while holding many relevant macro-contextual factors constant. While there are limits to the generalizability of any single-country study, a micro-level examination within this case proves useful for several reasons. First, examining variation within this single country can address the micro-dynamics of dissent and repression that cannot be identified using broad cross-national datasets. Second, following recent microlevel research repression, the study exploits local variation to examine the mechanisms underlying a process rarely observed with such fine-grained detail.

\section{EMPIRICAL Strategy AND ANALYSis}

Following the above argument, we expect a positive relationship between infrastructural damage and state repression. Infrastructural damage interrupts the state's ability to monitor dissidents as well as its ability to contain collective challenges before they break out. Tactical substitution leads the police to begin reactively repressing challengers. As the state recovers and rebuilds local infrastructure, we expect a decrease in reactive repression as the state again uses its power for preventative measures. We test these expectations by examining an earthquake shock, infrastructural damage, and governmental repression behavior. 
However, the potential concern of endogeneity presents a challenge to our inference. Repression could also influence development of existing infrastructure in the reversed causal direction. For instance, more resources on infrastructural development may be given to areas where the state anticipates the greater need to quell dissidence, and this creates an issue of reversed causality. To address this concern, our empirical analysis leverages a fuzzy spatial regression discontinuity design that exploits the fact that exposure to the 'treatment' (infrastructure damage) is affected by an exogenous and geographically discontinuous 'shock' (the earthquake in 1976). Since the relationship between the assignment variable (Motagua fault zones) and exposure to treatment (infrastructure damage) is probabilistic ('fuzzy') as opposed to deterministic ('sharp'), the regression discontinuity design mirrors instrumental variable approaches (Hahn, Todd and Van der Klaauw, 2001; Van der Klaauw, 2002). This geographically discontinuous exposure is visualized in Figure 1 where the black line represents the fault line and the red areas are the earthquake damage zones. Departments having the Motagua fault passing through have a high probability of infrastructural damage, though the damage is probabilistic and not deterministic. $^{12}$

Hence in our empirical design, we create a binary instrument variable indicating whether a municipality is located inside the fault zones and use it to instrument our treatment variable (infrastructural damage) and see how it changes the variation in the outcome (the onset of repression). To ensure that the earthquake shock is a valid instrument, several assumptions need to be met. One important assumption is the exclusion restriction; the instrument $(\mathrm{Z})$ does not have a direct causal effect on the outcome $(\mathrm{Y})$ and only affects changes in the outcome via the path through the treatment $(\mathrm{X})$ (Sovey and Green, 2011). We expect that the earthquake shock (Z) has no direct effect on the decision to repress $(\mathrm{Y})$ because repression behavior is a result of political calculation by

\footnotetext{
${ }^{12}$ The Izabal department (the furthest to the left), for example, has the Motagua fault passes through and some earthquake epicenters located, but it only suffered from limited infrastructural damage.
} 
the government and strategic responses to political threats. The decision to use violence has little to do with where a natural disaster took place. However, the earthquake shock can indirectly impact repression behavior through declined state capacity as our theory indicates, and one of the key areas of declined state capacity is local infrastructure (X), such as roads and communication systems, that facilitate police to monitor and control dissidence. While infrastructure is a key pathway that connects the instrument to our outcome, it is possible that the earthquake may indirectly affect the decision to repress via other backdoor paths, such as the level of dissent activity or local population change. In our analysis, we will control for dissent activity and demographic shifts to 'blocks' the potential backdoor paths that could circumvent the treatment variable. In other words, by holding the different kinds of challenger behavior and demographic changes constant, we can exclude the possibility that the earthquake shock affects the likelihood of repression by bypassing its influence through our main predictor-infrastructural damage. In the conflict scholarship, natural disasters, such as tsunami and earthquakes, are increasingly used as instruments in studying state or insurgent violence (Kikuta, 2019; Montalvo and Reynal-Querol, 2019), thus increasing our confidence in utilizing the earthquake shock as the instrument in our empirical design.

Instrumental variable design also relies on the assumptions of strong instrument and monotonicity. The instrument strength assumption requires our instrument to be strong enough to predict the treatment variable and we report the first-stage reduced form result in the Appendix Table A.1. It indicates a much higher risk of infrastructural damage for municipalities located inside the fault line zones compared to those located outside. The F-statistics test for the relevance of the excluded instrument in the first-stage easily passes the conventional threshold of 10 (22592.2) for a single instrument design, and the weak instruments test rejects the null at $\mathrm{p}<0.05$ level, suggesting that the instrument is sufficiently strong. In terms of the monotonicity assumption, it suggests that the proposed instrument should only affect the treatment in one direction for all individuals or units. 
Given the nature of natural disasters, the earthquake can only negatively impacts local infrastructure for all the affected areas and does not increase the infrastructure so this assumption is also reasonably satisfied.

The outcome variable is police repression. To measure repression, this study relies on Sullivan (2016) coding of the AHPN, which identifies more than 2,500 repressive acts incorporating a broad range of tactics, such as torture, politically motivated arrests, disappearances, and surveillance. Our measure of repressive uses these data to construct a binary variable for police repression at the municipal-month level. The 'treatment' variable, Infrastructural damage, is a variable ranging from 0 to 100 indicating the level of infrastructural damage in each municipality in Guatemala. In the fuzzy regression discontinuity analysis, it is instrumented by the exogenous 'assignment' variable, Motagua Fault zones, which is a binary variable indicating whether the fault line passes through the municipality. In all models, standard errors are clustered at the municipal level. ${ }^{13}$ The unit of analysis is at the municipality-month level and the period under investigation is from 1976 (when the earthquake struck Guatemala) to 1982 (when a new regime discontinuously increased the "level" of repression). ${ }^{14}$ The 2 SLS results are estimated using the estimatr package in $\mathrm{R}$.

To identify infrastructure's effect on political repression, we also consider alternative explanations for the level of repression. The empirical models hence control for the the ebb and flow of challengers' behavior as well as structural characteristics that are conceptualized as relatively static or slow-moving conditions that influence the underlying expectations for mobilization and repression.

The second-stage results are presented in Table $2 .{ }^{15}$ Infrastructural damage is instrumented by a binary variable indicating whether a given municipality is located inside or

\footnotetext{
${ }^{13}$ We also include time cubic polynomial to account for the temporal dependence(Carter and Signorino, 2010). The result is reported in Table A.2. In Table A.3, we've also reported the traditional way of using year dummies as duration-specific fixed effects, and the results remain consistent.

${ }^{14}$ For discussion of "levels" and "rates" of repression see Sullivan, Loyle and Davenport (2012).

${ }^{15}$ Variables are standardized for the ease of comparison.
} 
Table 2. IV Results (2SLS): Police Repression

\begin{tabular}{|c|c|c|c|c|}
\hline & 2 SLS & 2 SLS & 2 SLS & S-2SLS \\
\hline Infrastructural Damage & $\begin{array}{c}0.0033^{* * *} \\
(0.0013)\end{array}$ & $\begin{array}{l}0.0027^{* *} \\
(0.0013)\end{array}$ & $\begin{array}{c}0.0027^{* *} \\
(0.0013)\end{array}$ & $\begin{array}{c}0.0027^{* *} \\
(0.0013)\end{array}$ \\
\hline Overt Challenges & $\begin{array}{c}0.1930^{* * *} \\
(0.0226)\end{array}$ & $\begin{array}{c}0.1909^{* * *} \\
(0.0215)\end{array}$ & $\begin{array}{c}0.1896^{* * *} \\
(0.0215)\end{array}$ & $\begin{array}{c}0.1899^{* * *} \\
(0.0215)\end{array}$ \\
\hline Mobilization Activities & $\begin{array}{c}0.0361^{*} \\
(0.0210)\end{array}$ & $\begin{array}{c}0.0355^{*} \\
(0.0208)\end{array}$ & $\begin{array}{l}0.0354^{*} \\
(0.0207)\end{array}$ & $\begin{array}{l}0.0354^{*} \\
(0.0207)\end{array}$ \\
\hline Campaign Activities & $\begin{array}{c}0.0245^{* * *} \\
(0.0027)\end{array}$ & $\begin{array}{c}0.0236^{* * *} \\
(0.0027)\end{array}$ & $\begin{array}{c}0.0236^{* * *} \\
(0.0027)\end{array}$ & $\begin{array}{c}0.0236^{* * *} \\
(0.0027)\end{array}$ \\
\hline Insurgent Violence & $\begin{array}{c}-0.0884^{* * *} \\
(0.0231)\end{array}$ & $\begin{array}{c}-0.0889^{* * *} \\
(0.0220)\end{array}$ & $\begin{array}{c}-0.0881^{* * *} \\
(0.0220)\end{array}$ & $\begin{array}{c}-0.0882^{* * *} \\
(0.0220)\end{array}$ \\
\hline Ln Population & $\begin{array}{c}0.0076^{* * *} \\
(0.0017)\end{array}$ & $\begin{array}{c}0.0071^{* * *} \\
(0.0016)\end{array}$ & $\begin{array}{c}0.0071^{* * *} \\
(0.0016)\end{array}$ & $\begin{array}{c}0.0071^{* * *} \\
(0.0016)\end{array}$ \\
\hline HQ Location & & $\begin{array}{c}0.0051^{* * *} \\
(0.0016)\end{array}$ & $\begin{array}{c}0.0051^{* * *} \\
(0.0016)\end{array}$ & $\begin{array}{c}0.0051^{* * *} \\
(0.0016)\end{array}$ \\
\hline HQ Distance & & $\begin{array}{c}0.0025^{* * *} \\
(0.0009)\end{array}$ & $\begin{array}{c}0.0022^{* *} \\
(0.0009)\end{array}$ & $\begin{array}{c}0.0022^{* *} \\
(0.0009)\end{array}$ \\
\hline Democratic Inclusion & & $\begin{array}{c}-0.0149^{* * *} \\
(0.0017)\end{array}$ & $\begin{array}{c}-0.0128^{* * *} \\
(0.0016)\end{array}$ & $\begin{array}{c}-0.0132^{* * *} \\
(0.0018)\end{array}$ \\
\hline Spatial Lag & & & $\begin{array}{c}0.0053^{* * *} \\
(0.0014)\end{array}$ & $\begin{array}{l}0.0043^{* *} \\
(0.0018)\end{array}$ \\
\hline $\mathrm{R}^{2}$ & 0.4964 & 0.5053 & 0.5061 & 0.5061 \\
\hline Adj. $R^{2}$ & 0.4963 & 0.5051 & 0.5059 & 0.5059 \\
\hline Num. obs. & 27216 & 27216 & 27216 & 27216 \\
\hline F statistic & 155.1843 & 152.8317 & 139.6139 & 140.5551 \\
\hline RMSE & 0.1177 & 0.1166 & 0.1165 & 0.1166 \\
\hline N Clusters & 324 & 324 & 324 & 324 \\
\hline
\end{tabular}

outside the Motagua Fault zones. Model 1 shows that the level of infrastructural damage is a strong predictor for police repression, and the result is robust after controlling dissident activities, such as Overt challenges, Mobilization activities, Campaign actions, Insurgent violence, and Ln population. Model 2 further controls for structural factors such as $H Q$ location and $H Q$ distance as well as the level of Democratic inclusion. The results remain consistent. Transformations of infrastructural power appear to heavily impact decisions to repress. Substantively, shifts in infrastructural damage correlate with dramatic changes in the predicted rate of repression. Holding all else constant, a municipality experiencing infrastructural damage one standard deviation above the median experienced a ten-fold relative increase in the anticipated rate of repression. 
Spatial interdependence of police repression is likely present in our observations and failing to account for this spillover effect may lead to a biased result. Thus, we first include a spatially lagged dependent variable to account for the potential contagion of repressive violence across municipalities. The spatial lag is created by constructing a geographic connectivity matrix indicating whether two municipalities share borders. Model 3 in Table 2 shows that our result remains consistent by including the spatially lagged outcome. However, while this approach has been widely used to account for spatial interdependence, it may produce a system of simultaneously-determined, non-separable equations, and thus an endogenous spatial covariate (Wy). Betz, Cook and Hollenbach (2019) suggest that a better approach is to simply extend the IV framework using a spatial-two stage least square (S-2SLS) model by instrumenting for (Wy) and other endogenous variable of interest simultaneously. It is particularly useful when the instrument itself is also spatially clustered (i.e., rainfall or natural disasters). Therefore, we follow their guideline to estimate a S-2SLS model. The key step in this model is to find appropriate instrument for the spatial lag, and it is suggested by Betz et al. to transform our existing data and use the spatial lags of the exogenous predictors - covariates that exclude the spatial lag itself - to serve as instruments for the spatial lag of the outcome (Wy). ${ }^{16}$ The result of S-2SLS is reported in Model 4 showing that our result remains robust when using the S-2SLS model.

The results of our control variables largely confirm findings from the existing literature. For dissent behavior, increasing overt challenges, mobilization activity, and campaigns lead to a higher chance of repression in the local district. Interestingly, insurgent violence is negatively correlated with repression. More populous places are positively correlated with repression likely due to the increased chance of dissident movements. For structural covariates, we find that whether there is a police headquarter in the municipality is a

\footnotetext{
${ }^{16}$ The intuition can be shown by multiplying $\mathrm{W}$ by both sides of the same linear model $y=\beta x+e$ $\rightarrow \mathrm{Wy}=\beta W x+W e$.
} 
strong predictor for state repression; the spatial distance to the nearby headquarters also yields a significant prediction. Lastly, a higher level of democratic inclusiveness of the state decreases the likelihood of repression, which is consistent to the existing findings in the literature.

\section{Conclusion}

This study shows how police repression is conditioned by the relative balance between infrastructural and despotic power. Strong infrastructural power enables police to track and surveil dissident networks, substituting preemptive action for severe repression and "threat-response" escalations of violence. Repression becomes less needed for controlling political challenges as resistance can often be preemptively suppressed. However, when local infrastructural power is weakened, the state becomes less capable of gathering dissident information and taking preventative action, forcing the government to aggressively react to challenges when they emerge. Analysis of unique data on the behavior of the Guatemalan National Police confirms these expectations and reveals how decisions to repress are shaped by subnational variation in infrastructural power.

Understanding how infrastructural power regulates the use of repression inspires broad implications for research on conflict and policing. First, on a theoretical level, acknowledging that police are political actors further muddies the increasingly blurry lines delimiting conflict onset and cessation. Policing would-be political challengers provides the state with a crucial tool used to preemptively curtail potential conflict. Subsequently, the state appears less repressive because it does not need to rely on repressive responses to contain dissent. Second, turning to policy, this picture suggests that foreign development assistance intended to rebuild state infrastructure should be wary of human rights in conflict or disaster affected regions. Immediately after a natural disaster, states are likely to be more inclined to use police repression. Donors need to carefully monitor the situation and condition aid accordingly. 
While there are limits to the generalizability of any single-country study, this microlevel examination of state coercion provides some important insights in understanding repression strategies. First, theoretical consideration to both infrastructural and despotic power is essential for understanding repression and the enforcement of political order. Previous literature often views state repression as a response to dissent, emphasizing coercive reactions to events such as demonstrations or acts of rebellion. However, this perspective underplays the preventive measures states use to neutralize dissent. Based on the findings above, it is clear that the absence of repression does not necessarily indicate weak political control; instead, it often belies intense control operating through infrastructural power. Second, in cross-national studies states are often assumed to be unitary actors when exercising repression. However, in subnational analysis, the various roles of distinct security institutions come to light. For instance, police play a different role than the army in exercising repression. Local factors facilitate and restrain these agents, becoming important objects of study. Lastly, although our analysis is based on the context of the turbulent Guatemala civil war, the implication can be applied to broader contexts, especially repression in authoritarian regimes. There is rich local-level variation of repression in authoritarian regimes, such as Russia and China. The focus on the development of local policing infrastructure could provide a useful lens to explain when and where threat prevention is likely to fail, and more severe repression against challengers is anticipated.

Future research will benefit from examining the relationship between infrastructural and despotic power across a longer time period than that examined in this study. Investigating a regime's threat management strategy as the country goes through the extensive and drawn out processes of infrastructural buildup would be particularly fruitful. Over time, institutions regulating the growth of infrastructural power not only improve in their ability to make social behavior legible, but they also reform social roles and economic behavior into forms that are more easily monitored and measured by state bureaucrats. 


\section{ACKNOWLEDGMENTS}

The authors gratefully acknowledge the helpful comments and suggestions provided by editors of this special issue and participants at PSU's IR workshop, especially Douglas Lemke, Joseph Wright, Xun Cao, and Cyanne Loyle as well as participants at LSU's research seminar. We also appreciate the anonymous reviewers for their helpful comments.

\section{REFERENCES}

Arriola, Leonardo R., Aila M. Matanock, David A. Dow and Michaela Mattes. 2020. "Policing Institutions and Civil Conflict." Working Paper.

Bates, Frederick L, Charles D Killian and Walter Gillis Peacock. 1984. "Recovery, change and development: A longitudinal study of the 1976 Guatemalan earthquake." Ekistics pp. 439-445.

Betz, Timm, Scott J. Cook and Florian M. Hollenbach. 2019. "Spatial interdependence and instrumental variable models." Political Science Research and Methods p. 116.

Blair, Robert A. and Benjamin S. Morse. 2020. "Policing and the Legacies of State Predation: Evidence from a Survey and Field Experiment in Liberia." Working Paper

Blaydes, Lisa. 2018. State of Repression: Iraq under Saddam Hussein. Princeton University Press.

Brockett, Charles D. 2005. Political movements and violence in Central America. Cambridge University Press.

Butler, Christopher K and Neil J Mitchell. 2007. "Non-state actors, states, and repression: The effect of militias and informal armed groups on human rights violations." Unpublished manuscript .

Carter, David B and Curtis S Signorino. 2010. "Back to the future: Modeling time dependence in binary data." Political Analysis 18(3):271-292.

Collier, Paul et al. 2003. Breaking the conflict trap: Civil war and development policy. World Bank Publications.

Coppedge, Michael, Staffan Lindberg, Svend-Erik Skaaning and Jan Teorell. 2016. "Measuring high level democratic principles using the V-Dem data." International Political Science Review 37(5):580-593.

Cunningham, David. 2004. Theres something happening here: The new left, the Klan, and FBI counterintelligence. Univ of California Press.

Curtice, Travis. 2020. "How Repression Affects Public Perceptions of Police: Evidence from Uganda." Working Paper .

Davenport, Christian. 2007a. "State repression and political order." Annu. Rev. Polit. Sci. 10:1-23.

Davenport, Christian. 2007b. "State repression and the tyrannical peace." Journal of Peace Research 44(4):485-504. 
Davenport, Christian. 2009. "Regimes, repertoires and state repression." Swiss Political Science Review 15(2):377-385.

de la Policia Nactional, Archivo Historico, Carlos Aguirre and Kate Doyle. 2013. From Silence to Memory: Revelations of the AHPN. University of Oregon Libraries.

De Mesquita, Bruce Bueno, Alastair Smith, James D Morrow and Randolph M Siverson. 2005. The logic of political survival. MIT press.

DeMeritt, Jacqueline HR. 2015. "Delegating death: Military intervention and government killing." Journal of Conflict Resolution 59(3):428-454.

Doyle, Kate. 1999. "The end of secrecy: US national security and the imperative for openness." World Policy Journal 16(1):34-51.

Earl, Jennifer. 2011. "Political repression: Iron fists, velvet gloves, and diffuse control." Annual review of sociology 37:261-284.

Earl, Jennifer and Sarah Soule. 2006. "Seeing blue: A police-centered explanation of protest policing." Mobilization: An International Quarterly 11(2):145-164.

Espinosa, AF. 1976. "The Guatemalan Earthquake of February 4, 1976." US Geological Survey Professional Paper 1002:90.

Fariss, Christopher J and Keith E Schnakenberg. 2014. "Measuring mutual dependence between state repressive actions." Journal of Conflict Resolution 58(6):1003-1032.

Fearon, James D and David D Laitin. 2003. "Ethnicity, insurgency, and civil war." American political science review 97(1):75-90.

Foucault, Michel. 1991. The Foucault effect: Studies in governmentality. University of Chicago Press.

Gawronski, Vincent T and Richard Stuart Olson. 2013. "Disasters as crisis triggers for critical junctures? The 1976 Guatemala case." Latin American Politics and Society $55(2): 133-149$.

Giddens, Anthony. 1995. Time-space distanciation and the generation of power. In $A$ contemporary critique of historical materialism. Springer pp. 90-108.

Goldstone, Jack A and Charles Tilly. 2001. "Threat (and opportunity): Popular action and state response in the dynamics of contentious action." Silence and voice in the study of contentious politics pp. 179-94.

Greitens, Sheena Chestnut. 2016. Dictators and their secret police: Coercive institutions and state violence. Cambridge University Press.

Guberek, Tamy and Margaret Hedstrom. 2017. "On or off the record? Detecting patterns of silence about death in Guatemalas National Police Archive." Archival Science $17(1): 27-54$.

Gurr, Ted Robert. 1986. "Persisting patterns of repression and rebellion: Foundations for a general theory of political coercion." Persistent patterns and emergent structures in a waning century pp. 149-68.

Gurr, Ted Robert, Peter Nils Grabosky and Richard C Hula. 1976. Rogues, rebels, and reformers: a political history of urban crime and conflict. Sage publications Beverly Hills, CA.

Hahn, Jinyong, Petra Todd and Wilbert Van der Klaauw. 2001. "Identification and estimation of treatment effects with a regression-discontinuity design." Econometrica 69(1):201-209. 
Hill, Daniel W and Zachary M Jones. 2014. "An empirical evaluation of explanations for state repression." American Political Science Review 108(3):661-687.

Kikuta, Kyosuke. 2019. "Postdisaster reconstruction as a cause of intrastate violence: an instrumental variable analysis with application to the 2004 tsunami in Sri Lanka." Journal of conflict resolution 63(3):760-785.

Lucas, John. 1998. "The tension between despotic and infrastructural power: The military and the political class in Nigeria, 1985-1993." Studies in Comparative International Development 33(3):90-113.

Mann, Michael. 1984. "The autonomous power of the state: its origins, mechanisms and results." European Journal of Sociology/Archives européennes de sociologie 25(2):185213.

Masuda, Naoki, Hiroyoshi Miwa and Norio Konno. 2005. "Geographical threshold graphs with small-world and scale-free properties." Physical Review E 71(3):036108.

Montalvo, José G and Marta Reynal-Querol. 2019. "Earthquakes and terrorism: The long lasting effect of seismic shocks." Journal of Comparative Economics 47(3):541-561.

Moore, Will H. 2000. "The repression of dissent: A substitution model of government coercion." Journal of conflict resolution 44(1):107-127.

Nordås, Ragnhild and Christian Davenport. 2013. "Fight the youth: Youth bulges and state repression." American Journal of Political Science 57(4):926-940.

Olson, Robert A and Richard Stuart Olson. 1977. The Guatemala earthquake of 4 February 1976: Social science observations and research suggestions. In Mass Emergency. Vol. 2 Elsevier Scientific Publishing pp. 69-71.

Poulin, Robert. 2003. "The decay of similarity with geographical distance in parasite communities of vertebrate hosts." Journal of Biogeography 30(10):1609-1615.

Ritter, Emily Hencken and Courtenay R Conrad. 2016. "Preventing and responding to dissent: The observational challenges of explaining strategic repression." American Political Science Review 110(1):85-99.

Savun, Burcu and Daniel C Tirone. 2012. "Exogenous shocks, foreign aid, and civil war." International Organization 66(3):363-393.

Schlichte, Klaus. 2007. "Administering Babylon-On the Crooked Ways of State Building and State Formation." Politorbis. Zeitschrift fuer Aussenpolitik 42:34-39.

Scott, James C. 1998. Seeing like a state: How certain schemes to improve the human condition have failed. Yale University Press.

Slater, Dan and Sofia Fenner. 2011. "State power and staying power: Infrastructural mechanisms and authoritarian durability." Journal of International Affairs pp. 15-29.

Sobek, David. 2010. "Masters of their domains: The role of state capacity in civil wars.".

Sovey, Allison J and Donald P Green. 2011. "Instrumental variables estimation in political science: A readers guide." American Journal of Political Science 55(1):188-200.

Stanley, William. 1999. "Building new police forces in El Salvador and Guatemala: Learning and counter-learning." International Peacekeeping 6(4):113-134.

Sullivan, Christopher M. 2016. "Political repression and the destruction of dissident organizations: Evidence from the archives of the Guatemalan national police." World Politics 68(4):645-676. 
Sullivan, Christopher M, Cyanne E Loyle and Christian Davenport. 2012. "The coercive weight of the past: Temporal dependence and the conflict-repression nexus in the Northern Ireland Troubles." International Interactions 38(4):426-442.

Sullivan, Christopher Michael. 2012. "Blood in the village: A local-level investigation of state massacres." Conflict Management and Peace Science 29(4):373-396.

Sullivan, Heather. 2019. "Sticks, stones, and broken bones: Protest violence and the state." Journal of Conflict Resolution 63(3):700-726.

Tarrow, Sidney G. 1998. Power in movement: Social movements and contentious politics. Cambridge University Press.

Tilly, Charles et al. 2003. The politics of collective violence. Cambridge University Press.

Valentino, Benjamin, Paul Huth and Dylan Balch-Lindsay. 2004. "Draining the sea: mass killing and guerrilla warfare." International Organization 58(2):375-407.

Van der Klaauw, Wilbert. 2002. "Estimating the effect of financial aid offers on college enrollment: A regression-discontinuity approach." International Economic Review 43(4):1249-1287.

Weber, Eugen. 1976. Peasants into Frenchmen: the modernization of rural France, 18701914. Stanford University Press.

Weld, Kirsten. 2014. Paper cadavers: the archives of dictatorship in Guatemala. Duke University Press.

Yashar, Deborah J. 1999. "Democracy, indigenous movements, and postliberal challenge in Latin America." World Politics 52(1):76-104.

Yashar, Deborah J. 2005. Contesting citizenship in Latin America: The rise of indigenous movements and the postliberal challenge. Cambridge University Press. 